\title{
An Evaluation of Students' Practice of Using Reading Strategies in EFL Classes: The Case of Chagni General Secondary School Grade Ten in Focus
}

\author{
Gemechu Fufa,MA ${ }^{1^{*}} \quad$ Ebissa Bekele ${ }^{2}$ \\ Wollega University \\ Institute of Languages Study and Journalism, Department of English Language and Literature \\ Nekemte, Ethiopia, P O Box: 395
}

\begin{abstract}
The purpose of this study was to evaluate learners' practices of using reading comprehension strategies. A descriptive case study design which consisted of quantitative and qualitative data was used. The participants of the study were selected from 200 grade 10 students and English language teachers in Chagni General Secondary School. To this end, 60 students were selected through simple random sampling technique followed by lottery method for questionnaire and 4 English language teachers were also selected through purposive sampling technique for interview purpose. Three data gathering tools: questionnaire for students, classroom observation and semi-structured interview for teachers were used. Therefore, both quantitative and qualitative data analysis techniques were employed. As a result, the qualitative data was qualitatively analyzed to triangulate the quantitative data obtained through questionnaire. Thus, the result of the questionnaire, interviews and classroom observation showed that most students have negative attitude towards the reading strategy and strategy use. Moreover, most students were not using reading comprehension strategies in an EFL class when reading their instructional materials. The study concluded that there was a weakness of students in using reading comprehension strategies. It is also possible to conclude that most of the students were reading the instructional materials with no care of the strategies which were believed to maximize their text understanding. Moreover, lack of interest and awareness and lack of reading habit were among the major challenges to execute reading strategies in EFL classes. Lastly, the researcher suggested that the practice of reading strategies in EFL classes at Chagni General School needs continuous follow up.
\end{abstract}

DOI: $10.7176 / \mathrm{JCSD} / 66-02$

Publication date:August $31^{\text {st }} 2021$

\section{Introduction}

In the Ethiopian educational policy, English language is taught as a course starting from grade 1 to 12 and used as a medium of instruction starting from 9 to the higher education. Thus, Ethiopian students use this language to read and understand with the ability of constructing meaning from a certain text. Reading is a complex process that highly requires the use of various strategies which are vital in lifting comprehension (Brown, 1994). Therefore, there seems to be general agreement that a reading strategy is conscious procedure that facilitates comprehension and knowledge acquisition (Brantmeier, 2002). Thus, as it is central in all academic disciplines, the failure to usesuitable reading strategies greatly hampers comprehension and this in turn could adversely affect academic performance at large.

As to Hudson (2007), most of the comprehension activities of efficient readers take place at meta- cognitive level. Meta cognitive awareness, or Meta cognition, refers to one's ability to understand, control, and manipulate his/her own cognation process to maximize learning. In parallel with the above idea, Penn, Ur (1996) also defined the term as a means of reading and understanding'. A foreign language learner who says, 'I read the words, but I don't know what they mean' is not, therefore, reading in this sense. He or she is merely decoding translating written symbols into corresponding sounds (P.138).It is also asserted that reading comprehension is not simply recognizing individual words, or even understanding each individual word as our eyes pass over it. All models of comprehension recognize the need for readers to build up a mental representation of the text, a process that requires integration across a range of sources of information, from word features to knowledge concerning events in the world. For this reason, the simple view of reading, which could be seen as the first attempt to describe the "balanced literacy", suggests that reading comprehension results from developing skills in the areas of decoding and linguistic comprehension (Kirby \& Savage, 2008).

In this regard, comprehension of language does not only involve the understanding of individual words but also active engagement with the content to create a mental representation. This is due to the fact that successful comprehension requires coordination of skills at many levels to extract and construct meaning. The level of difficulty associated with comprehension of certain content depends on the complexity of the language being used. There are important differences between the language that we use in everyday conversations and the language used in school where everyday conversations are originally used to achieve daily tasks and share 
personal information. Academic language includes a different set of words, more complex grammatical structures and different text organization to express content that describes complex relationships (Zwiers, 2008).

Moreover, Sweet and Snow (2002) agree that the main goal of reading is to extract and construct meaning from the text. This is also due to the fact that reading comprehension is a complex cognitive ability requiring the capacity to integrate text information with the prior knowledge of the reader and resulting in the elaboration of a mental representation. On top, Abebech (2015) agreed that reading comprehension is an interactive process that takes place between a reader and a text and during this interaction; the reader brings variable levels of experiences and skills which include language skill, cognitive resources and world knowledge. In other words, it entails readers' knowledge of strategies for processing texts, the ability to monitor comprehension, and the ability to adjust strategies as needed (Pressley, 1998). This concept has offered great insights to let learners manage their cognitive activities to achieve comprehension before, during, and after reading. Cognitive strategies, on the other hand are one type of learning strategies that learners use in order to learn more successfully and includes making prediction, summarizing, translating and guessing meaning from the context, repetition and imagery for memorization and they all of these strategies involve deliberate manipulating of language to improve learning (Oxford, 1990).

Studies indicate that reading comprehension strategies can be taught. For example, once students' Meta cognitive knowledge about reading strategies and strategy use is developed, they will become better readers (Farrell, 2001; Sheorey and Mokhtar, 2001). Anderson \& Pearson, (2004) also stated that some of the active reading strategies that need to be cultivated in our students' mind through instruction and regular practice are: generating questions about ideas in text while reading; constructing mental images representing ideas in text; summarizing and paraphrasing; analyzing the text into components of setting, language structure, main idea, cohesive devices and transitions. As Snow (1998) in Tesfu (2015), the application of such reading comprehension strategies results in improved memory and comprehension of text for students. Hence, language educators insist on teaching students to use reading strategies in a self-regulated fashion with extensive teacher explanation and modeling of strategies, followed by teacher-scaffold use of the strategies, and culminating in student self-regulated use of the strategies during reading.

When reading to learn, students need to follow four steps: first, students need to figure out the purpose for reading; formulate background knowledge of the topic in order to predict or anticipate content and identify appropriate reading strategies (reading with purpose). Secondly, they should attend the parts of the text that are relevant to the identified purpose and ignore the rest (being selective). This selective reading activity enables students to focus on specific items in the input and reduces the amount of information they have to hold in shortterm memory. Thirdly, they need to select strategies that are fitting to the reading task and use flexibly and interactively; and finally, they need to check their comprehension while reading and after reading task is completed. Monitoring comprehension helps to detect in consistencies and comprehension failures, helping them learn to use alternative strategies. With this understanding, the benefits of reading comprehension strategy need to be considered as helpful and wisely applied so as to facilitate comprehension.

Yet, as the researchers' experience and observation in Chagni General Secondary School, it seems that most students are not practically using the suggested reading strategies to monitor their own learning. More than this, students lack willingness to engage in different classroom activities especially in an EFL reading class. In addition, some students informally reflect that they think teachers create additional activities so as to use the same as a means of punishing their students rather than for the benefit them. This implies that students are at low level of practice. Hence, this was the main reason that inspired the researcher to study the case. So, the aim of this study was to see grade ten students' understanding about reading strategies and to evaluate current actual practice of using reading comprehension strategies in an EFL class in Chagni General Secondary School.

\section{Objectives of the Study}

This study generally aimed to evaluate grade ten students' reading strategies use while reading instructional texts particularly in Chagni General Secondary School. The specific objectives of this study were:

1. To explore students' perceptions on reading strategies.

2. To evaluate the students' practice of using different reading strategies while reading instructional materials.

3. To explore the way grade ten students carry out reading strategies in EFL classes.

4. To explore the major challenges of implement reading strategies in EFL classes.

\section{Methodology and Design}

The purpose of this study was to evaluate students' practice of using reading strategies in EFL class, the researcher used descriptive case study in which the data could be collected through questionnaire, interview and classroom observation. The study used quantitative and qualitative research approach on the ground that it would help to get reliable and pertinent information. In line with this, Nunan (1992) states that descriptive case study is 
an intensive, holistic description and analysis of a single entity, phenomenon, or social unit. This scholar explains that descriptive Case study is particularistic and heuristic and relies heavily on inductive reasoning in handling multiple data sources. The study was conducted at Chagni Public General Secondary school, Western Amhara region, Awi Zone at Chgeni town $520 \mathrm{~km}$ from Addis Ababa, the capital. The school was selected purposively as most students have critical reading comprehension problems in reading instructional materials. In addition, the setting was convenient for the researchers to successfully run the study.

\subsection{Population of the Study}

The populations of the study were 200 Grade 10 students and 4 English language teachers at Chagni General Secondary School in 2012 E.C. The researcher used simple random sampling and purposive sampling to select the respondents. Probability sampling, namely, simple random sampling technique was used to select the student respondents as it was believed to offer equal chance for the entire population. Moreover, the teacher respondents were selected through census method. As far as the sample size for students is concerned, Cohen (2005) state that there is no clear-cut answer to determine how large a sample size for a research should be for the correct sample size depends on the purpose of the study and the nature of the population. But Kothari (2004) states that it is possible to take $20-30 \%$ sample size when using descriptive survey studies. So, the researcher took 60 students 15 in each of the 4 section that constitutes about $(30 \%)$ of the population. With regard to teacher participants, there are 4 English language teachers in Chagni General Secondary School and all four (4) $(1=$ male and $3=$ female) of them were taken through purposive sampling.

\subsection{Data Gathering Instruments}

The researcher employed different data gathering instruments: questionnaire (students), classroom observation and interview (for the teachers) for the researcher believed that the tools could help the researcher to obtain both valid qualitative and quantitative data for the best of the study. To validate the questionnaire, different ELT experts reviewed the tool and necessary amendments were made.

\subsubsection{Observation}

To see in to the students' actual practice of using reading comprehension strategies, $t$ he researcher made classroom observation. As Tesfu (2015) pointed out, observation is not simply a question of looking at something and then noting down 'the facts. Rather it is a complex combination of sensation (sight, sound, touch, smell and even taste) and perception. Observation involves the systematic viewing of people's actions and the recording, analysis and interpretation of their behavior. Kothari (2004) also states that the main advantage of using observation method is that subjective bias is eliminated if observation is done accurately. Secondly, the information obtained under this method relates to what is currently happening; it is not complicated by either the past behavior or future intentions or attitudes. Thirdly, this method is independent of respondents' willingness to respond and as such is relatively less demanding of active cooperation on the part of respondents as happens to be the case in the interview or the questionnaire method. As a result, the researcher used observation checklist with nine (9) items and observed each teacher for three times. The observation checklists were used to see into the way students apply reading strategies and to obtain relevant data about the way students carry out reading comprehension activities.

\subsubsection{Questionnaire}

The researcher collected the data through questionnaire adapted from the survey of reading strategies (SORS) by Mokhtari and Sheorey (2002) and that was developed to measure cognitive awareness and perceived use of reading strategies of adolescent and adult learners of English as second language; while, reading academic materials in English. The questionnaire consisted 30 items; the first 8 questions which were used to measure the way students perceive strategy use in reading class the rest items related to measuring the three broad categories of reading strategies: global reading strategies (GRS), problem-solving strategies (PSRS) and support strategies (SRS). A 5-point Liker scale following each item indicates the frequency of strategy use ranging from 1 (never) to 5 (always). Nunan (1992, P143) states that questionnaire is a relatively popular means of collecting data which enables the researcher to collect the required data in his/her desired area. The researcher used closed-ended questions followed with Likert- scale to assess students' perception on reading strategies, how often do students use reading strategies, how students use reading strategies in an EFL class and to explore the challenges of using reading strategies in EFL classes.

\subsubsection{Interview}

The researcher employed semi-structured interviews for participant teachers for it is flexible to obtain data. All the seven (7) items were self- developed based on insights obtained from literature review. Kothari (2004), states that an interview is purposeful to triangulate data that may not be obtained via other tools. The semi-structured interview for sampled teachers was used to obtain vital input about the practice of reading comprehension strategies and for eliciting rich data on people's views, attitudes and the meanings that underpin their lives and behaviors. Kothari, (2004) justifies that more information and that too in greater depth can be obtained when we 
use interview and the interviewer can usually control which person(s) will answer the questions. This is not possible in mailed questionnaire approach. The main purpose of the interview for this study is to obtain data in relation to the practices of reading strategies. The interview data were qualitatively analyzed using frequencies. To gather the data, the researcher first made classroom observation followed by questionnaire distribution to the respondents and finally interview was made with the subjects concerned. So, the data collected via close-ended questionnaire and classroom observation were analyzed quantitatively; while, the data obtained through interview were analyzed qualitatively.

\section{DATA ANALYSIS AND INTERPRETATION}

4.1. Students' Questionnaire Data Analysis

\subsubsection{Analysis of students Perceptions of Reading Strategies Use}

Hussein (2013) defined perception as a positive or negative evaluation of people, objects, event, activities, ideas, or just about anything in a persons' environment. To this end, the data obtained via questionnaire with regards to students' perceptions were numerically quantified as follow in Table 4.1.1.1 below.

\section{Table 4.1.1.1Students' Response on their Perception regarding Reading Strategies Use}

\begin{tabular}{|c|c|c|c|c|c|c|c|c|c|c|c|c|c|}
\hline \multirow[t]{3}{*}{ No } & \multirow[t]{3}{*}{ Statements } & \multicolumn{12}{|c|}{ Responses } \\
\hline & & \multicolumn{2}{|c|}{ SA } & \multicolumn{2}{|l|}{ A } & \multicolumn{2}{|l|}{ U } & \multicolumn{2}{|l|}{ D } & \multicolumn{2}{|c|}{ SD } & \multicolumn{2}{|c|}{ Total } \\
\hline & & $\mathrm{f}$ & $\%$ & $\mathrm{f}$ & $\%$ & $\mathrm{f}$ & $\%$ & $f$ & $\%$ & $f$ & $\%$ & $f$ & $\%$ \\
\hline 1 & $\begin{array}{l}\text { I understand that using reading } \\
\text { strategies in EFL class helps me } \\
\text { better comprehended the text. }\end{array}$ & 16 & 26.6 & 20 & 33.3 & 5 & 8.3 & 14 & 23.3 & 5 & 8.33 & 60 & 100 \\
\hline 2 & $\begin{array}{l}\text { I perceive using different reading } \\
\text { strategies enhance my } \\
\text { understanding. }\end{array}$ & 13 & 21.3 & 23 & 38.3 & 7 & 11.6 & 10 & 16.6 & 7 & 11.6 & 60 & 100 \\
\hline 3 & $\begin{array}{l}\text { I perceive that it is not easy to } \\
\text { understand written texts without } \\
\text { using reading strategies. }\end{array}$ & 14 & 23.3 & 24 & 40 & 5 & 8.3 & 10 & 16.6 & 7 & 11.6 & 60 & 100 \\
\hline 4 & $\begin{array}{l}\text { I think reading strategies are } \\
\text { helpful if used in reading class. }\end{array}$ & 15 & 25 & 24 & 40 & 10 & 16.6 & 15 & 25 & 6 & 10 & 60 & 100 \\
\hline 5 & $\begin{array}{l}\text { I always bored in the class when } \\
\text { the teacher models reading } \\
\text { strategies. }\end{array}$ & 10 & 16.6 & 12 & 20 & 8 & 13.3 & 9 & 15 & 21 & 35 & 60 & 100 \\
\hline 6 & $\begin{array}{l}\text { I perceive that using reading } \\
\text { strategies when reading academic } \\
\text { text makes learning difficult } \\
\text { especially in EFL reading class }\end{array}$ & 10 & 16.6 & 6 & 10 & 9 & 15 & 21 & 35 & 14 & 23.3 & 60 & 100 \\
\hline 7 & $\begin{array}{l}\text { I am not willing to use reading } \\
\text { strategies in reading class }\end{array}$ & 20 & 33.3 & 18 & 30 & 3 & 5 & 10 & 16.6 & 9 & 15 & 60 & 100 \\
\hline 8 & $\begin{array}{l}\text { I do not think that reading } \\
\text { strategies are helpful rather than } \\
\text { adding work loads }\end{array}$ & 18 & 30 & 16 & 26.6 & 7 & 11.6 & 15 & 25 & 4 & 6.6 & 60 & 100 \\
\hline
\end{tabular}

The respondents were asked to indicate their scale of agreement and disagreement with the statement related to their perception regarding reading strategies. The result in the table confirmed that most of the students $16(26.66 \%)$ strongly agree that using reading strategies helps them comprehend their instructional materials and also $20(33.33 \%)$ of the students reported they agree that they perceive positively that using reading comprehension strategies helps them to comprehend academic materials particularly in EFL reading class. Furthermore, $5(8.33 \%)$ of the respondents reported that they cannot decide that using reading strategies helps them comprehend their academic materials. On the other hand, $14(23.33 \%)$ of the respondents reported that they disagree that using reading strategies helps them comprehend their instructional materials and also $5(8.33 \%)$ of the respondents indicated that they strongly disagree that using reading strategies help them comprehend their academic materials. From this analysis the researcher concluded that the majority $36(70 \%)$ of the respondents have awareness about the importance of reading comprehension strategies.

As stated on item number 2 in the above table 4.1.1.1, $13(23.33 \%)$ of the respondents strongly agree and $23(38.33 \%)$ of the respondents also agree that using reading strategies enhance their understanding while reading instructional materials and $7(11.66 \%)$ of the respondents replied that they didn't decide that reading strategies enhance their understanding while reading instructional materials in EFL reading class. The rest 10 $(16.66 \%)$ of the respondents and $7(10.66 \%)$ of the respondents replied that they disagree and strongly disagree that reading strategies enhance their understanding respectively. Therefore, from the data analysis, the researcher 
found out that the majority $36(67 \%)$ of the respondents have good awareness about reading strategies among other students.

Item number 3 in table 4.1.1.1 requested the respondents to indicate scales of their agreement and disagreement in relation to the way they perceive that it is not easy to understand written texts without using reading strategies. Regarding this, 14 (23.33\%) replied that they strongly agreed; whereas, 7(11.66) replied that they strongly disagree that it is not easy to understand written texts without using reading strategies. Similarly, $24(40 \%)$ of the respondents agreed; whereas, $10(16.66 \%)$ of the respondents disagree with the statement that it is not easy to understand written texts without using reading strategies. From this analysis the one can conclude that few $17(28 \%)$ students lack awareness that it is not easy to understand written texts without using reading comprehension strategies.

As the students were asked to indicate their scale of agreement and disagreement with the statement related to their perception regarding reading strategies on item number 4 in the above table $4.1,15(25 \%)$ and 24 (40\%) the respondents pointed out that they strongly agree and agree respectively that reading strategies are helpful if well used in EFL reading class, and 10 (16.66) of the respondents were not able to decide whether it is helpful or not. However, the rest $15(25 \%)$ and $6(10.66 \%)$ of the respondents indicated that they disagree and strongly disagree with the statement that reading strategies are helpful if used in EFL reading class. From the data analysis, the researcher concluded that most of the students have good awareness that reading strategies are vital if used in reading classes though few students still lack awareness the strategy use in an EFL reading classes.

With a reference to the items 5 and 6 , which deals with students lack of comfort and a feeling of difficulties when teachers model reading strategies, $38(63 \%)$ of the respondents strongly agree that modeling reading strategies makes them bored and difficult for them, while, $18(30 \%)$ of the respondents agreed that modeling reading strategies makes them bored and difficult for them to practice. Whereas, $30(40 \%)$ of the respondents disagreed with the statement; while $35(45 \%)$ of the respondents strongly disagreed to the statement on the items. From analysis of the data the one concluded that nearly half of the respondents have negative perception about reading strategies due to lack of awareness that reading strategies are very helpful for students to understand what they read.

Regarding with item 7 in table 4.1.1.1, which asked students' scale of agreement on their willingness to use reading strategies, $20(33.33 \%)$ of the respondents marked that they strongly agree; similarly, $18(30 \%)$ of the respondents also answered that they agree that they are not willing to use reading strategies. $3(5 \%)$ of the respondents reported that they didn't decide whether they will or not. On the other hand, only $10(16.66 \%)$ and 9 $(15 \%)$ of the respondents answered that they disagree and strongly disagree that they are not willing to use reading strategies in an EFL reading class. From this it is clear for the researcher that the majority of the students have no awareness about the uses of reading strategies and which implied that only few students are willing to use the strategies.

Finally, the students were asked to indicate their scale of agreement and disagreement on the statement on item 8 in which, $18(30 \%)$ of the respondents replied that they strongly agree and, $16(26.66 \%)$ of the respondents replied that they agree to the item in point. In addition to this, $7(11.66 \%)$ of the respondents were not able to decide on their perception about the importance of reading strategies. However, $15(25 \%)$ and only 4 $(6.66 \%)$ of the respondents replied that they disagree and strongly disagree with the statement that 'reading strategies are helpful rather than adding work load.' This implies that only a few students perceive that reading strategies are helpful to better comprehend academic materials rather than loading them with a useless works.

\subsubsection{Students' Responses on the Practice of Using Reading Strategies}

All the items below refer to the students' practice of using reading comprehension strategies in reading instructional materials. However, to make the analysis clearer, the researcher used the existing systems in the literature to provide a categorization adapted from Mokhtari and Sheorey (2002, p. 4). Based on the above categorization, the data were divided in to three categories. Finally, they were tabulated, presented and analyzed as follows (See 4.1.2.1, 4.1.2.2, and 4.1.2.3). 
Table 4.1.2.1: Students' Response on the Practice of Global Reading Strategies

\begin{tabular}{|c|c|c|c|c|c|c|c|c|c|c|c|c|c|}
\hline \multirow[t]{3}{*}{ No } & \multirow[t]{3}{*}{ Statements } & \multicolumn{12}{|c|}{ Responses } \\
\hline & & \multicolumn{2}{|c|}{ Never } & \multicolumn{2}{|c|}{ Rarely } & \multicolumn{2}{|c|}{ Sometimes } & \multicolumn{2}{|c|}{ Usually, } & \multicolumn{2}{|c|}{ Always } & \multicolumn{2}{|c|}{ Total } \\
\hline & & $\mathrm{F}$ & $\%$ & $\mathrm{~F}$ & $\%$ & $f$ & $\%$ & f & $\%$ & $f$ & $\%$ & $\mathrm{f}$ & $\%$ \\
\hline 9 & $\begin{array}{l}\text { I have a purpose in mind when I } \\
\text { read }\end{array}$ & 20 & 33.3 & 16 & 26.6 & 14 & 23.3 & 5 & 8.3 & 5 & 8.3 & 60 & 100 \\
\hline 10 & $\begin{array}{l}\text { when I read, I try to realize if the } \\
\text { content of the text fits my } \\
\text { reading purpose }\end{array}$ & 26 & 43.3 & 11 & 18.3 & 9 & 15 & 9 & 15 & 5 & 8.3 & 60 & 100 \\
\hline 11 & $\begin{array}{l}\text { I review the text to know about } \\
\text { its main idea }\end{array}$ & 16 & 26.6 & 16 & 26.6 & 16 & 26.6 & 10 & 16.6 & 4 & 6.6 & 60 & 100 \\
\hline 12 & $\begin{array}{l}\text { When I read, I decide what to } \\
\text { read closely and what to ignore }\end{array}$ & 28 & 46.6 & 9 & 15 & 11 & 18.3 & 7 & 11.6 & 5 & 8.3 & 60 & 100 \\
\hline 13 & $\begin{array}{l}\text { I use my prior knowledge (e.g., } \\
\text { knowledge about the theme of } \\
\text { the text) to understand what I } \\
\text { read }\end{array}$ & 13 & 21.6 & 15 & 25 & 9 & 15 & 14 & 23.3 & 9 & 15 & 60 & 100 \\
\hline 14 & $\begin{array}{l}\text { I use tables, figures, and pictures } \\
\text { in text to increase my } \\
\text { understanding }\end{array}$ & 15 & 25 & 13 & 21.6 & 20 & 33.3 & 8 & 13.3 & 5 & 8.3 & 60 & 100 \\
\hline 15 & $\begin{array}{l}\text { I use context clues to better } \\
\text { understand what I read }\end{array}$ & 17 & 28.3 & 15 & 25 & 14 & 23.3 & 8 & 13.3 & 6 & 10 & 60 & 100 \\
\hline 16 & $\begin{array}{l}\text { I check my understanding when } \\
\text { I come across new information }\end{array}$ & 20 & 33.3 & 17 & 28.3 & 7 & 11.6 & 10 & 16.6 & 6 & 10 & 60 & 100 \\
\hline 17 & $\begin{array}{l}\text { I use bold to identify key } \\
\text { information }\end{array}$ & 6 & 10 & 10 & 16.6 & 26 & 43.3 & 8 & 13.3 & 10 & 16.6 & 60 & 100 \\
\hline 18 & $\begin{array}{l}\text { I predict about the text to get a } \\
\text { general idea of what it says } \\
\text { before I read it. }\end{array}$ & 24 & 40 & 15 & 25 & 10 & 16.6 & 7 & 11.6 & 4 & 6.6 & 60 & 100 \\
\hline
\end{tabular}

As shown in table 4.1.1.2.1 above, the students gave their response to the questions on how often they use global reading strategies. So, the data on item number 9 , shows that $20(33.33 \%)$ of the respondents never have a purpose in their mind when they read their academic materials. In the same manner, 16 (26.66) of the respondents also indicated that they rarely have a purpose in mind when they read their academic materials. In addition to these, $14(23.33 \%)$ of the respondents replied that they sometimes have a purpose in mind when they read their academic materials. However, $5(8.33 \%), 5(8.33 \%)$ of the respondents respectively replied that they usually and always have purpose in mind when they read their instructional materials. From this, one can realize that the majority of students always read their instructional materials without purpose in a mind.

Students were also asked to indicate whether or not they realize the content of the text fit their reading purpose. In line with this, the data showed that $26(43.33 \%)$ of the respondents never realize if the content of the text fit their purpose of their reading. Similarly, $11(18.33 \%)$ of the respondents also replied that they rarely do it; while, $9(15 \%)$ of the respondents reported that they sometimes realize whether the content of the text fit their purpose of reading the material. Only $9(15 \%)$ and $5(8.33 \%)$ of the respondents replied that they usually and always realize whether the content of the text fit their purpose of reading. So, the researcher concluded that most of the students did not realize if the content of the text fit their reading purpose and only a few students did it.

Item number 11 in table 4.1.1.2.1 above, also asked the students if they review the text to know its main idea. Here, the data indicated that $16(26.66 \%), 16(26.66 \%)$ respectively reported that they never and rarely review the text to know the main idea; while, 16 (26.66\%)of the respondents review the test sometime. However, $10(16.6 \%), 4(606 \%)$ of the respondents respectively proved that they usually and always review the text to know its main idea. This revealed that only few students always tried to review their instructional materials to get the main idea and also some students sometimes and as well as usually reviewed the text while more than half rarely and never did it.

As shown in table 4.1.1. 2.1, item 12, the students were asked if they decided what to read and what to ignore. With regard to this, their response revealed that $28(46.66 \%)$ of the respondents never decided on the material they read. Likewise, $9(15 \%)$ of the respondents also rarely decided what to read or what to ignore. Yet, $11(18.33 \%)$ of the respondents sometimes decided what to read and what to reject. Only $7(11.66 \%)$ and 5 $(8.33 \%)$ of the respondents respectively decide usually and always what to read or what to ignore. From the analysis one can understand that only few students always select what to read whereas majority of the students were unable to decide what to read or ignore. 
In item 13 the students were asked if they used their prior knowledge while reading their instructional materials. With this, $13(21.66 \%)$ of the respondents never used their prior knowledge when they were reading their instructional material. Similarly, $15(25 \%)$ of the respondents rarely used their prior knowledge. $9(15 \%)$ of the students sometimes use their prior knowledge. Still, $14(23.33 \%), 9(15 \%)$ of the respondents respectively usually and always used the prior knowledge when they read their instructional materials. From this we can see that majority of the respondents do not use their prior knowledge to comprehend the text.

Item 14 in table 4.1.1.2.1, requested the students to provide their answer on the extent to which they use tables, figures and pictures to increase their underfunding when they read their academic materials. With this question, $15(25 \%)$ of the respondents reported that they never used tables, figures and pictures to increase their understanding. $13(21.66 \%)$ of the respondents rarely used and $20(33.33 \%)$ of the respondents sometimes used tables, figures and pictures to increase their understanding; whereas, $8(13.33 \%)$ and the rest $5(8.33 \%)$ of the respondents usually and always use tables, pictures, figures and other aids in the text to increase their understanding. The data revealed that the majority of the respondents did not use the techniques to aid their text understanding.

Students were also asked if they use contextual clues to comprehend what they read as shown on table 4.1.1.2 item number 15. To this end, the respondents indicated the extent to which they used context clues to understand what they read. As an illustrated, $17(28.33 \%)$ replied that they never used contextual clues to maximize their understanding. Similarly, $15(25 \%)$ of the respondents marked that they rarely used. $14(23.33 \%)$ of the respondents sometimes tried to use and $8(13.33 \%)$ and only the rest $6(10 \%)$ of the respondents usually and always used context clue to comprehend what they read respectively. Therefore, the data analysis indicates that the majority of the respondents do not use contextual clues to understand what they read in their instructional materials.

As it is shown in table 4.1.1.2.1, on item number 16, respondents were asked to indicate their practice of checking their understanding when they come across new information. In relation to this, 20 (33.33\%), $17(28.33$ $\%), 7(11.66 \%), 10(16.66 \%), 610(6.66 \%)$ of the respondents respectively reported that they never, rarely, sometimes, usually and always practice checking their understanding when reading instructional materials. Here, the data analysis vividly revealed that the majority of the students did not check their understanding when they come across new information.

Item 17 in table 4.1.1.2.1 that request the students to put their answer with a reference to the extent to which they used typological features like bolds and italics, $6(10 \%)$ of the respondents never used bolds and italics to identify new information, 10 (16.66 \%) of the respondents also rarely used bolds and italics; whereas, 26 (43.33 $\%$ ) of the respondents sometimes used bolds and italics in order to get new information in their instructional materials. But, $8(13.33 \%), 10(16.66 \%)$ of the respondents respectively usually and always used bold and italics in order to understand what they read. Here, we can understand that the majority of the students use typological features to better comprehend what they read.

Item 18 in table 4.1.1.2.1 above enquired students if they predict the contents of the text before they read it. Regarding this, $24(40 \%)$ of the respondents never practiced predicting the contents of the text before they read it. Likewise, $15(25 \%)$ of the respondents rarely predict the contents of the text before reading the full text. Yet, $10(16.66 \%)$ of the respondents sometimes predict the text content before reading the text. $7(11.66 \%)$ usually predict and the rest $4(6.66 \%)$ of the respondents reported that they have a practice of predicting the content and main idea of the reading texts in their instruction materials. This analysis pointed out that only few of the respondents always tried to predict what the text would talk about before they read the material. On the other hand, the analysis indicated that the majority of the respondents have low practice of prediction of the contents of the reading text.

In general, with regard to the participants' use of global strategies, the result indicated that they tried to use only bolds and italics to extract new information and understand what they read in their text materials. Still, the participants appeared to have some problems, such as, confusion to decide what to read or ignore, reading the text with purpose, checking their understanding, predicting what the text would be about before reading the full text and activating prior knowledge to understand what they read.

\subsubsection{Problem Solving Reading Strategies Use}

The Problem-Solving reading strategies are localized focused problem-solving or repaired strategies used when problems develop in understanding textual information (e.g., re-reading for better understanding, going back when losing concentration, pausing and thinking about reading, etc.). 
Table 4.1.2.2:Students' Response on Problem Solving Reading Strategies

\begin{tabular}{|c|c|c|c|c|c|c|c|c|c|c|c|c|c|}
\hline \multirow[t]{3}{*}{ No } & \multirow[t]{3}{*}{ Statements } & \multicolumn{12}{|c|}{ Responses } \\
\hline & & \multicolumn{2}{|c|}{ Never } & \multicolumn{2}{|c|}{ Rarely } & \multicolumn{2}{|c|}{ Sometimes } & \multicolumn{2}{|c|}{ Usually } & \multicolumn{2}{|c|}{ Always } & \multicolumn{2}{|c|}{ Total } \\
\hline & & $\mathrm{f}$ & $\%$ & $\mathrm{~F}$ & $\%$ & $f$ & $\%$ & $f$ & $\%$ & $f$ & $\%$ & $f$ & $\%$ \\
\hline 19 & $\begin{array}{l}\text { I read slowly to understand what } \\
\text { I read }\end{array}$ & 14 & 23.3 & 18 & 30 & 11 & 18.3 & 8 & 13.3 & 9 & 15 & 60 & 100 \\
\hline 20 & $\begin{array}{l}\text { I try to adjust my reading speed } \\
\text { according to my reading purpose } \\
\text { what I am reading }\end{array}$ & 18 & 30 & 16 & 26.6 & 13 & 21.6 & 9 & 15 & 5 & 8.3 & 60 & 100 \\
\hline 21 & $\begin{array}{l}\text { I try to visualize information } \\
\text { from what I read }\end{array}$ & 17 & 28.3 & 15 & 25 & 15 & 25 & 6 & 10 & 7 & 11.6 & 60 & 100 \\
\hline 22 & $\begin{array}{l}\text { When a text becomes difficult, I } \\
\text { re-read it to increase my } \\
\text { understanding }\end{array}$ & 14 & 23.3 & 16 & 26.6 & 13 & 21.6 & 10 & 16.6 & 7 & 11.6 & 60 & 100 \\
\hline 23 & $\begin{array}{l}\text { When I read, I try to guess the } \\
\text { meaning of unknown words or } \\
\text { phrases }\end{array}$ & 16 & 26.6 & 14 & 23.3 & 14 & 23.3 & 6 & 10 & 10 & 16.6 & 60 & 100 \\
\hline
\end{tabular}

In the above table 4.1.2.2, students were asked to indicate the frequencies to which they used problem solving reading strategies. With a reference to item number 19 , the collected data indicated that, $14(23.33 \%)$ of the respondents never read slowly in order to understand what they read. $18(30 \%)$ of the respondents rarely read slowly to maximize their understanding. $11(18.33 \%)$ of the respondents sometimes read slowly to understand what they read whereas the rest $9(15 \%)$ of the respondents always tried to practice reading their academic materials slowly to understand what they read. Therefore, the majority of the respondents did not have the practice of reading a text slowly which means that the students read words, sentences and paragraphs without caring for their required understanding.

In the same table 4.1.2.2, item 20 , students were also asked to put the rate of frequencies of their practice of adjusting speed of reading. Regarding this practice, the respondents pointed out $18(30 \%)$ of the respondents never adjusted their speed according to their reading purpose. Similarly, $16(26.66 \%)$ of the respondents also rarely adjusted their reading speed based on purpose of their reading. $13(21.33 \%)$ sometimes, $9(15 \%)$ and the rest $5(8.33 \%)$ always adjust their reading speed according to their reading purpose. This analysis showed that most students did not adjust their reading speed based on the nature of the reading text and their purpose of reading. This in turns implies that most students did not worry for understanding their text rather than glancing through the text.

On item 21 in table 4.1.2.2, students were asked to indicate the frequency to which they visualize the information in text when they read. They indicated that $17(28.33 \%)$ of the respondents never tried to visualize what they read. $15(25 \%)$ of the respondents also answered that they rarely visualize or organize what they read in their instructional materials. However, $15(25 \%)$ of the respondents sometimes practice visualizing the contents of what they read. The rest $6(10 \%)$ and $7(11.66 \%)$ of the respondents reported that they usually and always tried to visualize information in their reading material when they read respectively. But, the result of the data analysis indicated that the majority of the students have low practice of visualizing the information, they read in their text materials. So, one can concluded that for most respondents reading is just glancing the text rather than trying to concentrate on and visualize what they read to comprehend their reading materials.

As shown in the same table, item 22, respondents indicated the extent to which they re-read the text to maximize their understanding. Concerning this, $14(23.33 \%)$ of the respondents never tried to practice rereading difficult texts. Likewise, $16(26.66 \%)$ of the respondents also rarely practiced re-reading to understand when the text become difficult. $13(21.33 \%)$ of the respondents usually re-read their instructional material to understand and the rest $7(11.66 \%)$ of the respondents always tried to re-read their material so as to increase their text comprehension skills. As it is clearly pointed out, it is proportional that half of the respondents have such practice of rereading their text materials to enhance their text comprehension while half of the respondents rarely and even never did it.

The final question on items 23 asked the students to indicate the extent to which they guess the meaning of new words or phrases. With a reference to this, $16(26.66 \%)$ of the respondents never had such practice and 14 $(23.33 \%)$ of the respondents rarely guess the meaning of words and expressions whereas $6(10 \%)$ of the respondents sometimes guess the meaning unknown words and expressions. 10 (16.66\%) of the respondent usually practiced guessing meanings of unfamiliar words and expressions. Likewise, $7(11.66 \%)$ of the respondents always practiced guessing the meaning of new words the face in their reading materials. From the analysis, the researcher concluded that the majority of the respondents have low practice of guessing meanings 
of new words and expressions they read in their instructional materials while less than half of the respondents did it.

Therefore, from the analysis of the whole item under Table 4.1.2.2, most of the respondents did not use problem solving strategies frequently probably because either they did not know these strategies very well or were not informed about the use of problem-solving text reading strategies.

\subsubsection{Support Reading Strategies}

The support reading strategies provide the support mechanism to sustain responses to reading (underlining or circling information, paraphrasing, taking notes, reading aloud, and using a dictionary, going back and forth in the text). Students were asked to indicate their practice on support reading strategies.

Table 4.1.2.3: Students' Response on Support Reading Strategies

\begin{tabular}{|c|c|c|c|c|c|c|c|c|c|c|c|c|c|}
\hline \multirow[t]{3}{*}{ No } & \multirow[t]{3}{*}{ Statements } & \multicolumn{12}{|c|}{ Responses } \\
\hline & & \multicolumn{2}{|c|}{ Never } & \multicolumn{2}{|c|}{ Rarely } & \multicolumn{2}{|c|}{ Sometimes } & \multicolumn{2}{|c|}{ Usually } & \multicolumn{2}{|c|}{ Always } & \multicolumn{2}{|c|}{ Total } \\
\hline & & No & $\%$ & $\mathrm{~F}$ & $\%$ & $\mathrm{f}$ & $\%$ & $\mathrm{f}$ & $\%$ & $\mathrm{f}$ & $\%$ & $\mathrm{f}$ & $\%$ \\
\hline 24 & $\begin{array}{l}\text { I take note of the key } \\
\text { expressions while reading } \\
\text { to understand what I read. }\end{array}$ & 7 & 11.6 & 24 & 40 & 11 & 18.3 & 10 & 16.6 & 9 & 15 & 60 & 100 \\
\hline 25 & $\begin{array}{l}\text { I paraphrase (restate ideas } \\
\text { in my own words) written } \\
\text { texts while I read to } \\
\text { understand better what I } \\
\text { read }\end{array}$ & 20 & 33.3 & 19 & 31.6 & 7 & 11.6 & 9 & 15 & 5 & 8.33 & 60 & 100 \\
\hline 26 & $\begin{array}{l}\text { I go back and forth in the } \\
\text { text to find relationships } \\
\text { among ideas in it }\end{array}$ & 17 & 28.3 & 20 & 33.3 & 13 & 21.6 & 4 & 6.6 & 6 & 10 & 60 & 100 \\
\hline 27 & $\begin{array}{l}\text { I ask myself questions } \\
\text { while I read to understand } \\
\text { the text. }\end{array}$ & 13 & 21.66 & 17 & 28.33 & 12 & 20 & 10 & 16.66 & 8 & 13.33 & 60 & 100 \\
\hline 28 & $\begin{array}{l}\text { While I read, I translate } \\
\text { English into my native } \\
\text { language }\end{array}$ & 8 & 13.33 & 14 & 23.33 & 15 & 25 & 13 & 21.66 & 10 & 16.66 & 60 & 100 \\
\hline 29 & $\begin{array}{l}\text { When read, I realize ideas } \\
\text { in English }\end{array}$ & 16 & 26.66 & 18 & 30 & 10 & 16.66 & 6 & 10 & 10 & 16.66 & 60 & 100 \\
\hline 30 & $\begin{array}{l}\text { I summarize what I read to } \\
\text { reflect important } \\
\text { information in the text. }\end{array}$ & 14 & 23.33 & 16 & 26.66 & 18 & 30 & 8 & 13.33 & 4 & 6.66 & 60 & 100 \\
\hline
\end{tabular}

Table 4.1.2.3 presented question to gather data about students' practice of using support reading strategies. Therefore, as indicted on item $24,7(11.66 \%)$ of the respondents never took notes when they were reading and similarly $24(40 \%)$ of the respondents also rarely took notes of the key expressions from what they read.11 $(18.33 \%)$ of the respondents sometimes took notes of the key expressions. $10(16.66 \%)$ of the respondents usually took notes and the rest $9(15 \%)$ always take a note of the key points from what they read. From the analysis one can see that the majority of the respondents do not take short note of key ideas and expressions while reading to understand the text.

In the same table item 25, students were asked to mark their answers regarding their practice of paraphrasing or restating written texts using their own words and expressions when they read their instructional materials. Following this, $20(33.33 \%)$ reported that they never restated or paraphrased the idea in the reading text using their own words. While, $19(31.6 \%)$ of the respondents reported that they rarely use the strategy mentioned. $7(11.66 \%)$ of the respondents reported that they sometimes paraphrased idea in their own words whereas $9(15 \%)$ of the respondents answered that they usually paraphrased idea of what they read and the rest 5 $(8.33 \%)$ of the respondents marked that they always tried to paraphrase or restate written texts by using their own words from what they read. As to the analysis, only a few students paraphrased what they read and from this one can concluded that there was weakness among the majority of the respondents in paraphrasing the contents of the reading material as they read their instructional materials.

Students also gave their answer concerning the practice of going back and forth in the text to find relationship among ideas. Here, $17(28.33 \%)$ of the respondents reported that they never go back to the text to see the relationship between idea in the text. More than these, $20(33.33 \%)$ of the respondents marked that they rarely go back to the text they read so as to see the connection of idea in that reading text. However, $13(21.33$ $\%$ ) of the respondents replied that they sometimes go back in to the reading text in order to see the relationship among the idea. $4(6.66 \%)$ students reported that they usually see in to the relationship among the idea in the 
reading materials whereas only the rest $6(10 \%)$ of the respondents always go back or forth to the text they read to notice the relationship between the idea in that text and as well as to maximize their comprehension. Hence, the analysis shows that the majority of the respondents did not try to realize the unity of the text they read. For this reason, we can say that there was a firm weakness in identifying the relationship of the idea in the text by going back in to the text in order to maximize their text comprehension skills.

As it can be seen from table 4.1.2.3, the students also indicated the frequency to which they ask themselves a question while reading their materials. As evidence showed, $13(21.33 \%)$ of the respondents reported that they never question themselves and $17(28.33 \%)$ of the respondents do. $12(20 \%)$ of the respondents answered that they sometimes practice self-questioning. $10(16.66 \%)$ of the students marked that they usually asked themselves to understand the text and the rest $8(13.33 \%)$ reported that they always forward question for themselves when the read their reading material. The analysis indicated that, the majority of the students have a practice of reading without questioning themselves. So, we can say that students' poorly practice selfquestioning to understand the text they read.

In table 4.1.2.3 with item number 28, the researcher requested the students to put their responses on the extent to which they translate idea in the written materials into their mother tongue language. In relation to this, 8 $(13.33 \%)$ of the respondents replied that never translated the idea in the reading text into their mother tongue language and $14(23.33 \%)$ of the respondents also replied that they rarely translate; whereas, $15(25 \%)$ of the respondents marked that they sometimes use their mother tongue language to translate the idea in the text. 13 $(21.33 \%)$ and the rest $10(16.66 \%)$ of the respondents replied that they usually and always tried to translate what they read in English into their mother tongue language. From this, we can understand that the majority of the respondents have a practice of translating words and expressions from English language in to their mother tongue language in order to maximize their understanding while there was weakness in the practice among some students in the same educational setting.

In the same table 4.1.2.3, item number 29 was used to measure the extent to which the students use English language to realize words and expressions of what they read. For this request, the respondents gave their answer as follow. $16(26.66 \%)$ of the respondents replied that they never use English language to realize words and expressions from what they read and $18(30 \%)$ of the students also answered that rarely used English to recognize the idea of the text they read whereas $10(16.66 \%)$ of the students marked that they sometimes recognized the idea of the text they read. $6(10 \%)$ of the students also reported that they usually used English and the rest $10(16.66 \%)$ of the respondents marked that they always practice realizing words and expressions of what they using English language. As a result, we can conclude that the majority of the respondents rarely and even never try to use the target language or English in order to conceptualize and realize the contents of the text they read. This in turns implies that there is weakness in practicing to recognize idea in English language to scale up their understanding.

In table 4.1.2.3, the final item number 30, was used to evaluate the actual practice of the students in summarizing the key concepts and point of what they read. Then as indicated $18(30 \%)$ of the respondents replied that they never practiced summarizing the key concepts of the text they read. Similarly $16(26.66 \%)$ of the respondents answered that they rarely practiced summarizing the main idea of the text they read whereas 14 $(23.33 \%)$ of the respondents replied that they sometimes summarize the key expressions. $8(13.33 \%)$ and the rest $4(6.66 \%)$ of the respondents marked that they usually and always summarize the key points of what they read. This reveals that most students do not summarize only the key idea of what they read in order to enhance their text comprehension. For this reason, we can conclude that they simply read the text without caring for their understanding. In generally, the effort was made to survey students' current practice related to using support reading strategies. Here, the data analysis shows that there was limitation in students' practice. For an illustration, most of the support reading strategies were not executed by students as expected. Thus, the failure in using these strategies leads the readers to misunderstanding of what they read.

\subsubsection{Challenges Affecting Use of Reading Strategies}

\subsubsection{Response on Students Challenges in Using Reading Strategies}

In order to identify the major challenges that deter students reading strategy use, seven questions were posed to the respondents. Thus, the results of the data analysis were given in Table 4.1.3 bellow. 


\begin{tabular}{|c|c|c|c|c|c|c|c|c|}
\hline $\begin{array}{l}\text { Scale } \\
\text { value } \\
\end{array}$ & \multirow[t]{2}{*}{ Statements } & & 4 & 3 & 2 & 1 & Total & Mean \\
\hline Items & & Fr\& \% & & & & & & \\
\hline \multirow[t]{2}{*}{1} & \multirow[t]{2}{*}{ Students lack of awareness and interest } & \multirow{2}{*}{ Fr\&\% } & 3 & 1 & 0 & 0 & 4 & \\
\hline & & & 75 & 25 & 0 & 0 & 100 & \\
\hline \multirow[t]{2}{*}{2} & \multirow[t]{2}{*}{ Shortage of time to cover the lessons } & \multirow[t]{2}{*}{ Fr\&\% } & 2 & 1 & 1 & 0 & 4 & \\
\hline & & & 50 & 25 & 25 & 0 & 100 & \\
\hline \multirow[t]{2}{*}{3} & \multirow[t]{2}{*}{ Students lack of good reading habit } & \multirow[t]{2}{*}{ Fr\&\% } & 1 & 1 & 1 & 1 & 40 & \\
\hline & & & 25 & 25 & 25 & 25 & 100 & \\
\hline \multirow[t]{3}{*}{4} & \multirow{2}{*}{$\begin{array}{l}\text { Teachers lack of training on teaching language } \\
\text { skills }\end{array}$} & \multirow[t]{3}{*}{ Fr\&\% } & 3 & 1 & 0 & 0 & 40 & \\
\hline & & & 75 & 25 & 0 & 0 & 100 & \\
\hline & Mean & & & & & & & 3.3 \\
\hline
\end{tabular}

Key: $4=$ Most serious $(A), 3=$ serious $(S), 2=\operatorname{Uncertain}(U), 1=$ Not serious $(N S)$

Generally, the results of the entire questionnaires data analysis indicated that the majority of the students have poor perception of the reading strategies, and were not practicing reading comprehension strategies for many reasons like students' lack of awareness, interest and lack of good reading habits. The classroom observation and interview data analyses also indicated the same finding with the questionnaire basically related to the major research questions and objectives of the study.

\section{Findings of the Study}

The purpose of this study was to examine the current practice of reading comprehension strategies in EFL classroom particularly in grade 10 at Chagni General Secondary School. The study intended to answer the following research questions.

1. What perceptions do students have with regard to the reading comprehension strategies?

2. How often do students practice reading comprehension strategies?

3. How do students carry out reading strategies in EFL classroom?

4. What are the major challenges of implementing reading strategies in EFL classes?

In order to answer these research questions, descriptive case study design was used. Literature review was made adequately to treat the key questions raised. Primary source of data was used as the main source. Data were collected using questionnaire, semi-structured interview, and observation. Finally, the study came up with the following findings which were based on students' perception about reading strategies, the actual practice of students in using the global, the problem solving and the support reading strategies. Furthermore, the finding also based on the way students apply reading strategies in EFL classroom and the major challenges of executing reading strategies in EFL classes.

1. In relation to students' perception about reading strategies and strategy use, the study revealed that there was negative outlook from the students on reading strategy use in an EFL class. The study reflected that the students were not willing to engage in comprehension activities. The interview and observation data reflected that there was weakness of creating awareness for the students about the functions of reading strategies in EFL classes.

2. Regarding reading comprehension strategies use, as it can be seen from students' response, classroom observation and interview data, the finding revealed the existence of limitations in practice. As the data analysis reflected, the practice of using global, problem solving and support reading strategies was very low. The results from the students' response also indicted that the frequency of using reading comprehension strategies is very limited between the ranges of "rarely" and "never". This shows that majority of the learners do not frequently use different reading comprehension strategies.

3. As indicated in the analysis part that data gathered from the interview, students were reading their instructional materials without using the model activities provided from the teachers. As the observation and interview data analysis revealed, the students appeared with low practice of answer comprehension questions using the appropriate reading strategies.

4. The data analysis indicated that, students' lack of awareness, lack of interest and lack of reading habit were among the major challenges to implement reading strategies in EFL classes.

\subsection{Conclusion}

Based on the above findings, the following conclusions were drawn.

1. It is possible to conclude that most students have no clear awareness about reading comprehension strategies and the importance of using reading comprehension to maximize their understanding. Furthermore, it is also possible to conclude that the students have not been addressed that using reading strategies is helpful of maximizing their text comprehension skills. 
2. It is possible to conclude that most students had low frequency of applying reading strategies the EFL classroom.

3. It is also possible to conclude that most of the students were reading their instructional materials with no care for the strategies which maximize their understanding.

4. Moreover, it is possible to conclude that lack of interest, awareness, and lack of reading habit were among the major challenges of implementing reading strategies in EFL classes.

\subsection{Recommendations}

Based on the above major conclusions, the following recommendations were suggested.

\# Teachers had better create awareness for students through frequent explanation about strategy and strategy use in class room.

\# Students should practice using different types of reading strategies in and out of classroom.

\# Students should use model reading comprehension questions provided by their teachers.

* Teachers should construct more different model activities from reading passages in the students' textbook in order to make students frequently apply different reading strategies.

* Teachers should prepare their reading passages from different sources by introducing, modeling, and implementing different reading strategies to create interest among the students towards strategy use.

* Students should be exposed to reading comprehension activities so as to develop their reading habit.

\# Finally, this study was limited only to grade ten students at Chagni General Secondary school. It would have been more comprehensive if more schools had been included in the study. Therefore, further research is needed to obtain better result.

\section{REFERENCES}

Abebech W/Michael (2015).Investigating the importance of reading comprehension strategies. M.A thesis: Debre Markos University.

Anderson,R.C.,andPearson,D.(1984).A schema-thematic view of basic process in reading comprehension in P.D. Pearson, R.Barr, M.1.Kamil, and P. Mosenthals (Eds.), Hand book of reading Research (pp.255-291).New York: Longman.

Brantmeir, C. (2002).Second language reading strategy research at the secondary and the University level: Variations, disparities and generalize ability. Reading Matrix: International on-line journal, 3(2).

Brown, D.(1994). Principles of Language Learning and Teaching.NewJersey: Prentice Hall, Inc.

Farrell, T.S. (2001).Teaching reading strategies: It takes time; Reading in a foreign Language, 1(3), 631-646.

Hudson,T.(2007).Teaching second language reading. Oxford, England: Oxford University press.

Mokhtari,K.,\& Reichard,C.A.2002. Assessing students' Meta cognitive awareness of reading strategies. Journal of Educational Psychology, 9(4) 22-32

Nunan, D. (1992). Research Methods in Language Learning. Cambridge: Cambridge University Press.

Oxford, R. (1990).Language learning strategies: what every teacher should know. New work: New bury House publishers.

Penny,Ur.(1996).A course in language teaching: practice and Theory. Great Britain. Practice. University press, Cambridge

Pressley, M. (1998).Reading instruction that works.The case for balanced teaching. The Guilford Press: New York, New York.

Sweet,A.P,and Snow,C.(2002).Reconceptualizingreadingcomprehension.InC.C.Biok,L.BGambrell,m.pressley(E ds.),Improvingcomprehension instruction(p. 17-53).san Francisco CA: Jossey-Bass. 